TRIANGULATING POETICS: LATE WALLACE STEVENS AND A NEW YORK SCHOOL Author(s): Lesley Janssen

Source: The Modern Language Review, Vol. 110, No. 4 (October 2015), pp. 992-1010

Published by: Modern Humanities Research Association

Stable URL: http://www.jstor.org/stable/10.5699/modelangrevi.110.4.0992

Accessed: 19-02-2016 15:12 UTC

\title{
REFERENCES
}

Linked references are available on JSTOR for this article:

http://www.jstor.org/stable/10.5699/modelangrevi.110.4.0992?seq=1\&cid=pdf-reference\#

references_tab_contents

You may need to $\log$ in to JSTOR to access the linked references.

Your use of the JSTOR archive indicates your acceptance of the Terms \& Conditions of Use, available at http://www.jstor.org/page/ info/about/policies/terms.jsp

JSTOR is a not-for-profit service that helps scholars, researchers, and students discover, use, and build upon a wide range of content in a trusted digital archive. We use information technology and tools to increase productivity and facilitate new forms of scholarship. For more information about JSTOR, please contact support@jstor.org. 


\section{TRIANGULATING POETICS: LATE WALLACE STEVENS AND A NEW YORK SCHOOL}

\section{Introduction}

In 1909, long before Frank O'Hara had a Coke at the Frick, Wallace Stevens was a young struggling lawyer alienated in New York City. Longing for the familiarity and natural surroundings of home, Stevens complained to his future wife, Elsie Moll, that 'the country here is simply a place where there aren't many houses. As a matter of fact, New-York makes itself felt for many miles in every direction.-And one can't say the people are nicer. There are so many of them. ${ }^{\prime}$ It would be hard to overstress the differences between Stevens's early New York experience and that of O'Hara, who revelled in his centrality as a social figure as much as he embraced the crowds and 'confines of New York' in his poem 'Meditations in an Emergency'. In the same poem, O'Hara claimed melodramatically: 'I can't even enjoy a blade of grass unless I know there's a subway handy, or a record store or some sign that people do not totally regret life.' In addition to the obvious differences from Stevens, such as O'Hara's characteristically playful, mocking tone, the latter's insistence on the social opportunities of New York City is striking. It is precisely in this social aspect that O'Hara was intent on distancing himself from the more solitary Stevens when he complained in 'Biotherm': 'I don't get any love from Wallace Stevens no I don't.'3

Despite such emotional rebuffs, this discussion proposes that it is nevertheless worthwhile to align Stevens and O'Hara, as their poetics share similarities which are not only mutually revealing, but also fundamental to a particular strand in post-war American poetics. In order to do so, this essay will read Stevens as being an unexpected member of the New York School. However, rather than considering the various aesthetic connections between Stevens and the poets coming after him as yet another case of poetic authority and Oedipal influence across generations, I will trouble any linear ascendancy by placing Stevens's aesthetics squarely in the middle of 1950 s New York. Specifically, my reading proposes an unusual poetic triangle in which Stevens, O'Hara, and John Ashbery form a significant cluster in American poetry at mid-century. While there are antecedents to this critical enterprise, such as Andrew Epstein's recent book on the New York School and Siobhan Phillips's work, my ambition is to pursue these initial, mostly conjectural attempts

${ }^{1}$ Letters of Wallace Stevens, ed. by Holly Stevens (Berkeley: University of California Press, 1966), p. 147.

2 Frank O'Hara, 'Meditations in an Emergency', in The Collected Poems of Frank O'Hara, ed. by Donald Allen (1977; repr. Berkeley: University of California Press, 1995), pp. 197-98 (p. 197).

3 O’Hara, 'Biotherm', in Collected Poems, pp. 436-48 (p. 439). 
beyond their present scope. ${ }^{4}$ Also notable in this regard is Alan Filreis's self-styled 'whimsical' coda to Wallace Stevens, New York, and Modernism, in which he reads Stevens, Ashbery, and O'Hara synchronically 'as a kind of cohort'. To this end he composes 'a sample of an I-do-this-I-do-that Stevens, strolling, contradictory, irritably loving New York's stimulation, mixing art and perishables', based on the letters Stevens wrote during the same years in which the New York School began to emerge. ${ }^{5}$ While Filreis's reliance on the cohort successfully composes a sort of pseudo micro-history of Stevens as part of the New York School, I read these authors' joint poetics on a larger, transpoetical level in an attempt to give the notion of poetic triangulation a more solid grounding.

In essence, what I seek to offer is a thought-experiment about a significant stage in the twentieth-century evolution of American poetics that would help suggest alternative ways of reflecting on writers, rather than providing new applied close readings of particular poems. For that reason, this project brings together, and expands upon, a handful of suggestive, but not fully developed, intrinsically compatible readings in order to demonstrate their complementarity and to strengthen the validity of the triangulation developed here. To set up this experiment, the first part of my discussion sketches the historical background of our expanded New York School, all the while readjusting the O'Hara-Stevens connection by using Ashbery's poetics as a relay. Ideally, my poetic triangulation shifts our critical focus towards a more flexible, social, and collective praxis that might reveal as much about supposed disciples as it does about father figures. More specifically, the social impetus that this reveals in all three poets may be mixed with a potent strain in the history of American poetics that is evident equally in late Stevens and the New York School's nascent poetics. This could be summed up as a celebratory pragmatism that presents itself most clearly in the aesthetic portrayal of, and engagement with, the everyday, and is perhaps most obvious in what poetry critic Roger Gilbert conceived of as the 'walk poem'. ${ }^{6}$ Here, especially, my work engages with recent critical debates that have placed quotidian poetics at the centre of reappraisals of Stevens's late work. In the second part of my discussion,

4 Andrew Epstein, Beautiful Enemies: Friendship and Postwar American Poetry (Oxford: Oxford University Press, 2006). My present suggestion to try out unconventional poetic triangles follows through on Epstein's claim that 'aesthetic and cultural forms cannot be fully understood through the study of individual authors in isolation or solely as manifestations of external sociopolitical conditions, but rather should be seen as a product of densely interwoven cultural, intertextual, interpersonal spaces' (p. 5). See also Siobhan Phillips, 'Stevens and an Everyday New York School', Wallace Stevens Journal, 36 (2012), 94-104.

5 Alan Filreis, 'Coda: Wallace Stevens of the New York School', in Wallace Stevens, New York, and Modernism, ed. by Bart Eeckhout and Lisa Goldfarb (New York: Routledge, 2012), pp. 163-69 (p. 163).

${ }^{6}$ See the introduction of Gilbert's Walks in the World: Representation and Experience in Modern American Poetry (Princeton: Princeton University Press, 1991), pp. 3-48. 
O'Hara's 'Rhapsody' acts as a litmus test against which the implications of these triangulated poetics are read in Stevens's late work and Ashbery's collection Some Trees (1951). Finally, the limitations of my poetic model are tested by teasing out the problems that arise when a poem is pragmatically and radically defined by its occasion, and how that, in turn, affects notions of the self.

\section{Setting the Scene: On Unconventional Alliances}

While I aim to steer clear of classic models of influence, such as the one proposed in Harold Bloom's influential, deeply agonistic The Anxiety of Influence, the importance of the traditional critical mode is still obvious. This is partly because Bloom was crucial in helping to chart Stevens's legacy: he is probably foremost among poetry critics who have been sceptical about collective ways of reading avant-garde poetry in America. ${ }^{7}$ Thus, while Bloom has for a long time championed Ashbery as the 'strongest' poet of his generation, in particular when 'he dares to write most directly in the idiom of Stevens', he has also been most eager to sever Ashbery's ties to the larger collective of the New York School. ${ }^{8}$ Bloom argues polemically that 'Ashbery can be regarded as either the best poet by far of the "New York" School or-as I would argue-so unique a figure that only confusion is engendered by associating him with Koch, O'Hara, Schuyler and their friends and disciples.' ${ }^{\prime}$ Notwithstanding Bloom's protests, the relationship between Ashbery and O'Hara-poetic and otherwise-has continued to fascinate critics, who have re-evaluated it carefully in the last few years. Thanks to this surge of interest in poetic interactions among members of the New York School, a case can easily be made for reading Ashbery and O'Hara together, in particular when we wish to examine how these poets engaged with Stevens. ${ }^{10}$

At first glance, admittedly, this may seem like a counterintuitive cluster: most critical approaches present Ashbery and O'Hara as opposite poles on a continuum of poetic dialogues with Stevens. Certainly, we have enough evidence to suggest that the young poets both worshipped Stevens. In a 1950 letter to O'Hara about Stevens's little-known poem 'Yellow Afternoon' (included in Parts of a World (1942)), Ashbery-then only 23-reports that the poem 'completely floored [him] with its greatness'. Despite Ashbery's playful

7 See Epstein, pp. 5, 7.

${ }^{8}$ Harold Bloom, Figures of Capable Imagination (New York: Seabury Press, 1976), pp. 169, 172.

9 Ibid., p. 169.

${ }^{10}$ See Epstein, as well as Marjorie Perloff, Frank O'Hara: Poet among Painters (Austin: University of Texas Press, 1979); Mark Silverberg, The New York School Poets and the Neo-Avant-Garde: Between Radical Art and Radical Chic (Farnham: Ashgate, 2010); Lytle Shaw, Frank O'Hara: The Poetics of Coterie, Contemporary North American Poetry Series (Iowa City: University of Iowa Press, 2006). 
claims of poetic surrender-'every time I read it I am ready to turn in my chips and become an osteopath'-we know that he would actually model his own poem 'Illustration' on Stevens's example. ${ }^{11}$ Ashbery later included the poem in his first volume, Some Trees, for which W. H. Auden awarded him the Yale Younger Poets Prize in 1951. In an enthusiastic review of this book, O'Hara, the runner-up for the award, established the Stevensian connection when he described the collection as being 'the most beautiful book to appear in America since Harmonium' ${ }^{12}$ Since those early notes of appreciation, Ashbery has consistently been linked to Stevens, in both critical and popular appraisals. However, in later years (from about the 1970s onwards) Ashbery himself has attempted to downplay and complicate the critically imposed debt to Stevens: 'I don't consider myself an avatar of Wallace Stevens. It's true that some of my earlier work sounds very much like Wallace Stevens, but I certainly don't think it does throughout [...] and I don't think Wallace Stevens would have thought so either.' ${ }^{\prime 3}$

In marked contrast, Ashbery's Harvard friend O'Hara has always been read separately from Stevens. Early appraisals of the poet, such as Marjorie Perloff's ground-breaking Frank O'Hara: Poet among Painters, note the poet's 'respectful distance' from Stevens. ${ }^{14}$ Yet, in contradiction of the younger poet's apparent dismissal of Stevens, O'Hara's biographer Brad Gooch offers a revealing anecdote from the early 1950 s that indicates how both O'Hara and Ashbery originally shared their enthusiasm about Stevens:

'One day I ran into John and Frank on Massachusetts Avenue and they started saying that Stevens was a more important poet to them than Eliot, who was a huge influence on half the professors at Harvard,' recalls Harold Brodkey. 'They wanted to abandon Eliot for Stevens and they wanted me to go along with them. They were very superior about being over Eliot's kind of exaltation and incantation and upper-level meaning. It made me feel very stodgy.'15

For O'Hara, the hieratic, upper-level meaning of Eliot's specific kind of modernism - where Eliot was mainly a straw figure for a poetics that Ashbery and O'Hara undiscerningly tended to group together with the formalist poetry of the New Critics, and the confessional verse of poets such as Lowell-was irrelevant in his own demotic, coterie poetics. Elaborating on this contrast, critics described O'Hara's flattened-out poems as snapshot or Polaroid poetry (Helen Vendler's phrase), or likened its deceptively straightforward textual

11 Ashbery, quoted in Brad Gooch, City Poet: The Life and Times of Frank O'Hara (New York: Knopf, 1993), p. 173 .

12 O’Hara, 'Rare Modern', Poetry, 89 (1957), 307-16 (p. 313).

13 Ashbery, quoted in Michael Davidson, 'Notes beyond the Notes: Wallace Stevens and Contemporary Poetics', in Wallace Stevens: The Poetics of Modernism, ed. by Albert Gelpi (Cambridge: Cambridge University Press, 1985), pp. 141-6o (p. 143).

14 Perloff, Frank O'Hara, p. 61.

15 Gooch, p. 138. 
surface to a 'landscape without depth' (in Charles Altieri's description). ${ }^{16}$ Forgoing the seriousness of high modernism, O'Hara's ruminations were rooted firmly in the joys and caprices of the everyday-the topic of so many recent discussions of Stevens's poetics as well. In response to the everyday, O'Hara's language was transparent, tended to avoid high-cultural references, and resisted being subsumed by larger philosophical frameworks, all the while achieving remarkable emotional depth.

Following through on the haphazard 'I do this, I do that' mode of the younger poet, Edward Ragg has made a first attempt at bringing Stevens and O'Hara closer together by arguing that Stevens's 'natural inclinations were those of O'Hara (adamantly in the "all art" camp): resistant to assimilation into "too many philosophic frames"'. ${ }^{17}$ Poetic affinities such as these are sufficient first indications that the connection between O'Hara and Stevens is up for revaluation. Accordingly, recent criticism has made several strides towards reducing the gap between Stevens and O'Hara. Phillips's analysis of the correspondences between Stevens and the New York School is a good case in point: she reveals the younger poets' 'appropriation of Stevens's quotidian poetics' and suggests that their reworking of Stevens's influence could in turn help us 'substantiate the elegiac and social aspects of Stevens's ordinary repetitions'. ${ }^{18}$ The poetic engagement with these 'ordinary repetitions' may be regarded as typical of the late 1950s response to Stevens, when 'the narrow critical focus on Harmonium and Stevens's "pure poetry" gradually began to broaden' and readers found that Stevens's 'ability to participate in and celebrate the everyday rather than the transcendent was exactly his distinction and value'. ${ }^{19}$ Surveying the field of Stevens criticism published in 2012, finally, Jeffrey Blevins relies on Stevens's quotidian language to read O'Hara's later poetry: 'The impending re-experience of a quotidian event, even if it is just lunch (as in O'Hara's Lunch Poems), is its own kind of ecstasy as shared ritual. $^{\prime 20}$ Still, O'Hara's own insular focus on coterie writing kept him oblivious of the fact that he had crucial quotidian impulses in common with Stevens.

By 1965, O'Hara's description of Stevens in 'Biotherm' as the 'poète américain | lyrique et profond' creates the image of a Gallicized (read post-

\footnotetext{
${ }^{16}$ Helen Vendler, Part of Nature, Part of Us: Modern American Poets (Cambridge, MA: Harvard University Press, 1980), p. 179; Charles Altieri, Enlarging the Temple: New Directions in American Poetry during the 1960s (Lewisburg: Bucknell University Press, 1979), p. 110.

17 Edward Ragg, Wallace Stevens and the Aesthetics of Abstraction (Cambridge: Cambridge University Press, 2010), p. 3.

${ }_{18}$ Phillips, 'Stevens and an Everyday New York School', p. 95.

19 John Timberman Newcomb, Wallace Stevens and Literary Canons (Jackson: University Press of Mississippi, 1992), p. 173.

${ }^{20}$ Jeffrey Blevins, 'Survey Review of a Year's Essays on Stevens: A Quotidian Ecstasy', Wallace Stevens Journal, 37 (2013), 253-61 (p. 258).
} 
Symbolist, distanced) lyric 'I': a loftily transcendent figure whom the reader does not 'get any love from'. O'Hara, it seems, insists on casting Stevens as a poet whose work shies away from a social connection with both the material world and the reader:

I think délices is a lot of horseshit and that comes from one who infinitely

prefers bullshit

and the bank rolled on

and Stevens strolled on

an ordinary evening alone

with a lot of people. ${ }^{21}$

In these lines, O'Hara manages to subvert Stevens's aphorism that 'Money is a kind of poetry', ${ }^{22}$ and also critiques the poet-figure's retreat into the ivory tower of self-sufficient contemplation. O'Hara singles out 'An Ordinary Evening in New Haven' as exemplifying Stevens's failure to connect socially to the everyday world: the poet is doomed to be 'alone with a lot of people'. Yet there is an interesting conflict in such an assessment, for 'An Ordinary Evening' is a poem that could easily be connected to Stevens's inherently social, quotidian poetics. ${ }^{23}$ In addition, Stevens's insistence that 'the poet looks at the world somewhat as a man looks at a woman' suggests a deeply amorous relation with the world that potentially unsettles O'Hara's depiction of the older poet, as various critics have argued. ${ }^{24}$

Though it is easy enough to counter O'Hara's reading of Stevens, it remains curious that O'Hara finds fault with Stevens's engagement with the interpersonal in particular. After all, while O'Hara's own 'Personism' provocatively 'puts the poem squarely between the poet and the person, Lucky Pierre style, and the poem is correspondingly gratified'25-so that the poetic encounter is in essence sexualized and socialized-his own coterie writing has often been criticized for its own kind of insularity. O'Hara's poetic reliance on intensely personalized spaces has been regarded as an elitist manœuvre that distances him from worldly events transpiring outside, pace Lytle Shaw's counter-argument that coterie writing helped subvert 'midcentury rhetorics of universality' and created 'alternative models of kinship, both social and literary'. ${ }^{26}$ In accordance with Shaw, I would argue that, although Stevens and

21 O'Hara, 'Biotherm', p. 439.

22 Wallace Stevens, 'Adagia', in Wallace Stevens: Collected Poetry and Prose, ed. by Frank Kermode and Joan Richardson (New York: Library of America, 1997), pp. 900-15 (p. 905).

${ }^{23}$ See Gilbert, pp. 75-106; see also Phillips's reading of Stevens's quotidian poetics in 'Stevens and an Everyday New York School'.

${ }^{24}$ Stevens, 'Adagia', p. 905. See also Helen Vendler, Words Chosen out of Desire (Knoxville: University of Tennessee Press, 1984), and the various contributions to Stevens' Erotic Poetics, ed. by Angus Cleghorn (= Wallace Stevens Journal, 30.2 (2006)).

25 O'Hara, 'Personism: A Manifesto', in Collected Poems, pp. 498-99 (p. 499).

${ }^{26}$ Shaw, p. 6. See also pp. 3-5 for critiques of O'Hara's social engagement. 
O'Hara connected differently to these public spheres, the interplay between their poetics suggests that their shared insistence on a flexible pragmatism and the random occasions and trivialities of life gave rise to an analogously celebratory, social poetics.

\section{Closing the Triangle: From O'Hara to Ashbery-and Back to Stevens?}

My initial notes here suggest that O'Hara's poetical examination of the social and the everyday allies his poetry with key impulses in Stevens's late work. As James Longenbach already claimed several years ago, in the revealingly entitled Wallace Stevens: The Plain Sense of Things, '[ $\mathrm{t}$ ] he condition Stevens alternately spoke of as the ordinary, the humdrum, or the commonplace was an achievement - a middle ground that was not a compromise between extremes. Ideally, it represented a position from which extremes, aesthetic and political, were clearly assessed. ${ }^{27}$ More recent work, such as Liesl Olson's Modernism and the Ordinary, suggests, moreover, that in Stevens's poetic model 'the commonplace is collective', and that it 'is not a complete or finished phenomenon but always transpiring'. ${ }^{28}$ Olson's focus on the social impulses of Stevens's poetics is crucial as it mitigates attacks on both Stevens's seeming dismissal of the interpersonal (similar to O'Hara's), and what has been construed as Longenbach's 'generalized centrism' ${ }^{29}$ Such criticism argues for an iteration of the idea that Stevens's middle ground reinforces or supports poetical autonomy 'by imagining him as floating at an equal distance from all ideological points'. ${ }^{30}$ Similarly, Ashbery's focus on the mimetic workings of the mind has been held against him as a lack of social or interpersonal interest-with some critics arguing that Ashbery has done nothing more than exacerbate Stevens's 'irresponsibility in relation to others'. ${ }^{31}$ As the triangle proposed here is starting to tease out, these assessments fail to take into account an insistence on the shared experience of poetry: it is a common ground that is always transpiring. In other words, the poet's engagement with the everyday implies a pragmatic, non-dogmatic position in which the middle ground becomes a collective social notion-a shared ritual, if you will-that allows the poet to test all heterodoxies. The poet's middle point is never in the middle; or at least, it is not there for very long.

27 James Longenbach, Wallace Stevens: The Plain Sense of Things (New York: Oxford University Press, 1991), p. viii.

${ }^{28}$ Liesl Olson, Modernism and the Ordinary (New York: Oxford University Press, 2009), pp. 131, 118.

29 A critique levelled against him recently by Andrew Goldstone in Fictions of Autonomy: Modernism from Wilde to de Man (Oxford: Oxford University Press, 2013), p. 153. This ties in with Mark Halliday's assessment of Stevens's lack of social awareness in the contested Stevens and the Interpersonal (Princeton: Princeton University Press, 1991).

30 Goldstone, p. 153.

${ }^{31}$ In particular Halliday, p. 157. Later criticism mainly rehashes Halliday's reading. 
Another way of casting this pragmatist stance can be found in O'Hara's emphasis on occasional poetry, whose overtones of community and coterie proved to be crucial in the development of his emergent poetics. O'Hara mainly came into contact with the notion of occasional poetics via Paul Goodman's 1951 essay for the Kenyon Review, which stressed coterie writing and its social implications. ${ }^{32}$ Michael Davidson makes occasional poetics central to the dialogue between post-war poetry and Stevens. Davidson's early attempt to identify the transformation in post-war American literature of a poetry of place into one of occasions suggests that self-reflexive, autonomous poetics have become unmoored in post-war poetry to make way for a Stevensian description without place. ${ }^{33}$ The literary-historical scenario proposed by Davidson implies a turn in poetry away from the would-be stability of autonomous art-making to a more flexible, occasional poetics that dynamically engages with, and continuously rewrites, place. I would argue that it is precisely this shift from the stability of place to the mobility and social implications of the occasional poem - in essence another version of quotidian poetics-that has proved to be crucial for the nexus between Stevens, Ashbery, and O'Hara, and the post-war poetry we may associate with these authors' strand of writing.

In O'Hara's case, the 'I do this, I do that' mode of his mature poetry is perhaps his most fully realized form of occasional poetry. His collection of Lunch Poems aims to eliminate almost entirely the gap between occasionthe poet's lunchtime walks through New York City-and text. Along these lines, it has important affinities with the wandering and mentally digressive poetry of Ashbery. In that poet's case, the immediate experience-or direct occasion-of the poem becomes more abstracted and less important than the mind's attempt to transcribe the 'experience of experience'. ${ }^{34}$ For Ashbery, as Gilbert argues in Walks in the World, 'an occasion' is more than merely the subject: it acts as the 'experiential context of which the poem is itself a part'. 35 Even Ashbery's least referential poetry, Gilbert observes, is still the 'cry of its occasion'. ${ }^{36}$ That famous phrase from Stevens's 'An Ordinary Evening' makes full use of the ambiguities of the preposition 'of' as it invokes simultaneously its subjective and objective usages. ${ }^{37}$ This implies that the poem is as much of as about its occasion: though place is, then, continuously rewritten as a

32 See Gooch, pp. 186-87.

33 Davidson, p. 157.

34 Ashbery, quoted in Gilbert, p. 234.

35 Gilbert, p. 235.

${ }^{36}$ Stevens, 'An Ordinary Evening in New Haven', in Collected Poetry and Prose, pp. 397-417 (p. 404).

37 David Letzler, 'The Problem of $O f$, the Evasions of $A s$, and Other Grammatical Curiosities in Stevens's "An Ordinary Evening in New Haven", Wallace Stevens Journal, 36 (2012), 206-24 (p. 208). 
process of change, it remains always-in varying degrees-the anchor of the poem. ${ }^{38}$

Such poetic negotiations of poem and experience are perhaps elucidated most clearly by returning to Gilbert's conception of the 'walk poem', a quintessentially American mode that is set up as 'a brief excursion directed toward no practical goal but undertaken purely for the pleasures of movement, reflection, and aesthetic perception'. ${ }^{39}$ In this sense clearly shaped by American pragmatism, the walk poem is unique because, rather than focusing on the static notion of place, it aims to represent experience. For this reason, Gilbert usefully characterizes the walk poem as a lyric genre working in the mode of transcription rather than description: transcribing implies the carrying into language of something fluid and temporal', whereas describing 'or writing of suggests the linguistic representation of something fixed'. $4^{\circ}$ If O'Hara's poetry is walk poetry in its most literal sense, Ashbery's mental walks clearly fall into the conception of the walk poem as well, as their endless elaborations aim to enact the fluidity and transience of experience itself. The similarity is indeed part of how the poetics of both writers reflect the unsettling of aesthetic autonomy and closed poetic form we associate with the New York School. At the same time, the characteristics of the walk poem are also strikingly congruent with Stevens's affirmative quotidian poetics, which renders the ordinary as a 'discursive style: a roundabout, circular feat of never pinning down the elusive subject'. ${ }^{41}$ In Stevens's case, this not only highlights a celebration of the everyday but also reveals his scepticism of the transcendent and of static world-views. It allows him to take satisfaction, as he writes in 'It Must Give Pleasure' (the third and final part of 'Notes toward a Supreme Fiction'), in the act of going

round and round, the merely going round, Until merely going round is a final good, The way wine comes at a table in a wood. ${ }^{42}$

Rather than taking the more conventional route of mapping influence by tracing the implications of Stevens's pleasurable repetitions in the work of his younger followers, let me attempt to work my way back from O'Hara to Stevens, via Ashbery. In doing so, my reading will be circling around the shared social, quotidian poetics that I have been developing so far. One of the most paradigmatic O'Hara poems by which to demonstrate the dynamic rewriting of place-the being-in-the-moment that is typical of the writer's

${ }^{38}$ See Gilbert, pp. 95-98.

39 Gilbert, p. 3.

${ }^{40}$ Ibid., p. 8.

41 Olson, p. 118.

42 Stevens, 'Notes toward a Supreme Fiction', in Collected Poetry and Prose, pp. 329-52 (p. 350). 
poetics-is the significantly entitled 'Rhapsody'. The poem superimposes polarities such as jungle and city, high and low, tunnel and elevator, New York, Europe, and Africa: spatial and geographic shifts that create 'a multivalent sense of place as local and global, familiar yet exotic, real but surreal'. ${ }^{43} \mathrm{Char}-$ acteristic of this writing is its light, improvisatory style-or, as O'Hara urged, 'you just go on your nerve'. ${ }^{44}$ On one level, the poet's reliance on a paratactic, dislocated style aligns him with the 'languaged' Stevens at his most freely improvisatory as a linear reading of the poem is continuously complicated by various textual counterforces. The reader is forced to reshape the text, actively traversing the surface of the poem, much as he or she would roam through the city whose intrinsic dynamics and semiotic multiplicity such poetry reflects and enacts.

In 'Rhapsody' the same loss of a stable footing from which to examine and order the poem is reflected in the poet's inability to navigate the city itself: O'Hara wonders, 'where is the summit where all aims are clear?'45 Even though O'Hara seeks the high ground 'in the towering needle' of a building on Madison Avenue, the city below never fully structures itself in front of him. Instead, it becomes 'a stringless labyrinth', and the reader gets lost in a tentative maze of polarities that is constantly being reimagined by the poet. The verticality and stability of the high ground from which to observe things safely-suggestive of Davidson's sense of place-is inextricably tied up with the horizontality and occasional nature of the social realities of the world below. The poem shifts all of a sudden from the high ground of the Empire State Building to '9th Street and 1st Avenue' below, and back to the jungle fantasy of the 'Niger' and the 'Victoria Falls', eventually transforming 'Manahatta' into some exoticized island: 'lying in a hammock on St. Mark's Place sorting my poems | in the rancid nourishment of this mountainous island'. The poet, who 'always wanted to be near it', finds himself implicated in all the different social strata of New York, which leads to the poetic 'I' becoming a fluid, contingent self without a privileged vantage-point in a place that never crystallizes completely. ${ }^{46}$

This desire for immediacy and resistance to stability not only reveals O'Hara's affinity with Stevens and Ashbery but also implicitly questions the codifying logic of the hegemonic 1950 s Cold War culture and poetry. The shift from place, which implies an aesthetic and ethical point of origin (a vantage-point above and beyond the social world), to the dynamism

${ }^{43}$ Hazel Smith, Hyperscapes in the Poetry of Frank O'Hara: Difference/Homosexuality/Topography (Liverpool: Liverpool University Press, 200o), p. 64.

44 O'Hara, 'Personism', p. 498.

45 All quotations in this paragraph are from O'Hara, 'Rhapsody', in Collected Poems, pp. 325-26 (p. 326).

${ }_{46}$ See also Smith, p. 66, for the Whitmanian connection. 
of social appropriations of place (that is, occasions) tends to disrupt highmodernist, self-reflexive autonomy. This can be linked, albeit indirectly, to O'Hara's stylistic techniques. His reliance on apposition, metonymy, and syntactic dislocation adds to the joyful deferral of meaning and unity in his poetic world-view: 'Nothing really happens to the poet; it is all conditional, potential, projected into a possible future. ${ }^{47}$ We find a similar insistence on contingency in Ashbery's endlessly elaborating poems, his obscuring of personal reference, and in the poet's proclivity for writing imaginative, mental journeys. The poet's escape from the menial tasks of an office clerk in 'The Instruction Manual' is a good example:

And as my way is, I begin to dream, resting my elbows on the desk and leaning out of the window a little, Of dim Guadalajara! City of rose-colored flowers! ${ }^{48}$

The technical language of the poet's instruction manual forms a foil for the potentialities of the imagined occasions and meetings in the exoticized Mexican town of Guadalajara. The implied dismissal of an inflexible, defined manual suggests a constantly shifting, multivalent, poetic construction of the world contradicting what our poets saw as stale modernist attempts to arrest and fixate social flux in a neat aesthetic whole-thereby sounding a clear echo of Stevens's and O'Hara's lighter modes.

\section{Triangulating Poetics: Towards the Fluidity of Self}

The walk poem's insistence on flexibility and process has implications for the poetic notion of the self as well. In 'Rhapsody' and 'The Instruction Manual', for instance, the poetic 'I' is constructed as a series of fleeting presences that continuously emerge and disappear. The key importance of this constantly evolving self validates our triadic cluster even further, especially when we bring in Stevens's 1951 MoMA lecture, 'The Relations between Poetry and Painting'. ${ }^{49}$ Although Ashbery and O'Hara did not attend it, Stevens's lecture placed himself in what would later become a focal point for the New York School (O'Hara starting work at MoMA a few months later). As Filreis hazards, if the two younger poets had been in the audience, they might have recognized their own 'emergent poetics' in Stevens's language:

there is the conveying of instantaneities, there is the satisfaction of particulars, there is the cognizance that anything is available as composition, and doubt about the remnant

47 Perloff, Frank O'Hara, p. 122.

48 John Ashbery, 'The Instruction Manual', in Collected Poems 1956-1987, ed. by Mark Ford, The Library of America (New York: Library of America, 2008), pp. 5-8 (p. 6).

49 Stevens, 'The Relations between Poetry and Painting', in Collected Poetry and Prose, pp. $740-51$. 
self, and the familiar intelligence, and imitations within imitations, and there is the prodigious search for appearance. ${ }^{50}$

Aside from the obvious touchstones for Ashbery and O'Hara, Filreis's summary of Stevens's lecture highlights specifically those notions that I have suggested to be fundamental for the quotidian poetics and pragmatist inflections developed here. It is complementary to what the critic has elsewhere set up as a 'languaged Stevens' in opposition to the more traditional 'meditativelyric Stevens' associated with Romanticism. The 'languaged Stevens' is no 'conservator of lyric tradition, no defender against decay, trivialization, or mock'; instead, he highlights 'rhetoric's general centrality' and opts for the 'contingent' and 'unrevelatory'. ${ }^{1}$ Arguably, this kind of writing also taps into the "'queerer" side of modernism' that Mark Silverberg, in his discussion of the New York School, has pitted against the 'mainstream poetic art in the 1940 os and 50 s. $^{52}$ In addition, the insistence in Stevens's lecture on particulars and the teasing out of the self mirrors a crucial part of the New York School aesthetic: namely, the importance in derailing the contemporary poetic cult of the author, which by mid-century manifested itself in the wandering Beat soul, on the one hand, and the troubled Confessional poet, on the other.

Ashbery's scepticism of self and his predilection for shifting appearances are apparent early on. In 'The Picture of Little J. A. in a Prospect of Flowers' the poet admits: 'I cannot escape the picture | Of my small self in that bank of flowers.' Yet his search for appearances and imitation unsettles the static 'I', and the poet decides:

\section{I am not wrong}

In calling this comic version of myself The true one. ${ }^{53}$

The comic version revels in the idea of a shifting appearance: the self is only as definite as the next one that comes along. In a complementary way, O'Hara downplays assertions of the poet's ego by observing laconically that 'the strange career of a personality begins at five and ends $\mid$ forty minutes later in a fog'. He is 'the opposite of visionary', 54 and in his insistence on instantaneities 'never allows himself, or his readers, to confuse will and perception or to mistake careful rhetorical construction for discovered ontological or

50 Filreis, 'Coda', p. 166.

${ }^{51}$ Alan Filreis, 'The Stevens Wars', Boundary 2, 36 (2009), 183-202 (pp. 191, 192).

52 Silverberg, p. 172.

53 Ashbery, 'The Picture of Little J. A. in a Prospect of Flowers', in Collected Poems 1956-1987, pp. 13-14 (p. 14).

54 O'Hara, 'For the Chinese New Year \& For Bill Berkson', in Collected Poems, pp. 389-93 (p. 392), and 'In Memory of My Feelings', in Collected Poems, pp. 252-57 (p. 256). 
psychological truth'. ${ }^{55}$ Instead, the poet simply participates in the everyday. To this end, O'Hara's walk poetry demands that 'poetry is experience': it obscures the gap between text and occasion, making it appear as if the poems are a simultaneous transcription of the walk itself. ${ }^{56}$

Because there is no longer any stable footing in this poetics of radical presences and continuous process, there is also no longer a vantage-point from which to order the self, the world, or the past. On a larger level, this 'trope of abandonment and its corollary, self-dissolution' falls under the pragmatist inflection of experimental poetry as Epstein recently described it. ${ }^{57}$ The same 'strange notion that selfhood consists of an on-going evasion of self', ${ }^{58}$ however, also appears in Stevens's decidedly less experimental poetry. For instance, when the speaker in 'The Motive for Metaphor' addresses part of himself in the second person to remind himself,

you yourself were never quite yourself,

And did not want nor have to be,

Desiring the exhilarations of changes:

The motive for metaphor, shrinking from

The weight of primary noon,

The A B C of being. ${ }^{59}$

The three poets' acceptance of self-dissolution can be a liberating act when tied up, once more, with the social implications of quotidian aesthetics: 'what remains is a processual series of encounters with absences and presences (negations, affirmations) that amount to a poet's ecstatic participation in reality, not supremacy over it'. ${ }^{60}$ This is reflected both in O'Hara's desire 'to be near it' and in Ashbery's suggestion that he is happy with his flowing sense of self: 'I guess I don't have a very strong sense of my own identity. ${ }^{\text {'1 }}$ Famously, Ashbery translated this claim poetically in 'Self-Portrait in a Convex Mirror' as the idea that 'one | is always cresting into one's present'. ${ }^{62}$ Paradoxically, however, this constant revision of the self, characteristic of both Stevens's and the New York School's poetics, relies on the accompanying notion of community: the dissolution of the self is contingent on the shared experience of the everyday. This is especially palpable in Ashbery's contention that, at

55 Altieri, Enlarging the Temple, p. 118.

56 Gilbert, p. 176.

57 Epstein, p. 23, see also pp. 67-68.

58 Ibid., p. 23.

59 Stevens, 'The Motive for Metaphor', in Collected Poetry and Prose, p. 257.

60 Blevins, pp. 254-55.

${ }^{61}$ O'Hara, 'Rhapsody', p. 326, and Ashbery, quoted in Marjorie Perloff, “"Transparent Selves": The Poetry of John Ashbery and Frank O'Hara', Yearbook of English Studies, 8 (1978), 171-96 (p. 195).

62 Ashbery, 'Self-Portrait in a Convex Mirror', in Collected Poems 1956-1987, pp. 474-87 (p. 483). 
least aesthetically, 'we are somehow all aspects of a consciousness giving rise to the poem'. ${ }^{63}$

Along the same lines, O'Hara's coterie writing has been defined as 'a shifting rhetoric' preoccupied with 'the social possibilities of affinity', or alternatively as an attempt 'to sustain a group of like-minded individuals by involving itself in their shared occasions' ${ }^{64}$ Moreover, the poet's radical insistence on the instant implies that he always writes Meditations in an Emergency: inconclusive reflections 'like a final chapter that no one reads because the plot is over' ${ }^{65} \mathrm{At}$ times, however, O'Hara's poetics seems to be troubled by the limitations of the fluid self, too easily flickering in and out of the moment. A recurrent sense of anxiety plagues his desire to capture the rush of experience directly, and at times he seems to question the satisfaction of particulars. O'Hara voices his own sense of transience in 'To the Harbormaster', the opening poem of his first collection, when he announces: 'I am always tying up | and then deciding to depart.' ${ }^{66}$ That refusal to stand still implies that the poet might eventually get 'caught in some moorings'. Or, as he admits in his first collection's eponymous prose poem, 'Meditations in an Emergency':

My eyes are vague blue, like the sky, and change all the time; they are indiscriminate but fleeting, entirely specific and disloyal, so that no one trusts me. I am always looking away. Or again at something after it has given me up. It makes me restless and that makes me unhappy. ${ }^{67}$

Eventually the desire, inherent in O'Hara's materialistic poetry, to capture every fleeting moment directly and instantaneously stretches the poet to his limit. His failure, or unwillingness, to rely on any form of poetic abstraction and distancing - which is perhaps the main mark of differentiation from Ashbery and Stevens-leads to a cul-de-sac where he can look back on his poetry and walks only self-doubtingly:

I was back in town!

what a relief!

I popped into the nearest movie-house and saw two marvelous Westerns

but, alas! this is all I remember of the magnificent poem I made on my walk why are you reading this poem anyway? ${ }^{68}$

By using the past tense, O'Hara radically questions his belief that experience is poetry and effectively undercuts his earlier poetry's attempts at merging

${ }_{63}$ Quoted in Perloff, 'Transparent Selves', p. 195.

64 Shaw, p. 6, and David Herd, John Ashbery and American Poetry (New York: Palgrave, 200o), p. 10.

65 O'Hara, 'Meditations in an Emergency', p. 198.

66 O'Hara, 'To the Harbormaster', in Collected Poems, p. 217.

67 O'Hara, 'Meditations in an Emergency', p. 197.

68 O'Hara, 'Petit Poème en Prose', in Collected Poems, p. 427. 
occasion and text. ${ }^{69}$ As a result, O'Hara struggles with the question of why the reader would still be interested in the static poem, so hopelessly trapped in the past. For the poet, all interest in the walk is lost, which becomes apparent when he comes upon 'the poured concrete dome' of a 'not very interesting' dump. The poetic confrontation with so many static relics of the past becomes an insurmountable hurdle that effectively immobilizes the poet:

hopping and skipping along

in my scarf which came to my heels

and soon caught on a doorknob. ${ }^{70}$

With O'Hara's trip to the dump it becomes clear that the poet, approaching middle age, found it increasingly difficult to accept when the new became old, or when the past repeated itself. By contrast, Stevens's 'The Man on the Dump' is less hindered by the pastness of the trash and 'feels the purifying change' when one orders, selects, and 'rejects | The trash'. ${ }^{71}$ More particularly, by reworking and appropriating the past, the poem stresses the communal 'value of cultural continuity'. ${ }^{2}$ In contrast, O'Hara's characteristic insistence on the present, and his revelling in the intensely personalized space and personalia of the coterie, seem to baulk at history in a dismissal of temporality. ${ }^{73}$ However, the limits of this ideal are seemingly built into O'Hara's poetic model. In the elegiac 'A Step Away from Them', for instance, the poet's celebration of the 'now' breaks down when confronted with immutable loss:

Bunny died, then John Latouche,

First

then Jackson Pollack. But is the earth as full as life was full, of them?74

How does one deal with the pastness of the past, when the poem is allowed to exist only in the moment?

One possible way out of O'Hara's predicament is offered in both Stevens's and Ashbery's less conspicuously materialistic, less directly mimetic poetry. Where O'Hara desires that the poem somehow manages to be experience, a speech act that performs the encounters with people and objects on the poet's walk-what Stevens elsewhere dismisses as 'the journalism of subjects'-

69 Gilbert, p. 195.

70 O'Hara, 'Petit Poème en Prose', p. 427.

71 Stevens, 'The Man on the Dump', in Collected Poetry and Prose, pp. 184-86 (p. 185).

72 Longenbach, p. 207.

73 See also Shaw, p. 20, for a de Manian reading of O'Hara's reliance on coterie, and the thematization of his social circle by inserting proper names into the poems to create a 'humanist refuge against temporality'. While the coterie 'represents an attempt to freeze time, to repress temporality and loss by filling these voids imaginatively with the would-be presence of a secure identity within a coterie', this is a 'temporary disillusion' [sic? not: illusion?] that ultimately breaks down.

74 O’Hara, 'A Step Away from Them', in Collected Poems, pp. 257-58 (p. 257). 
Stevens and Ashbery focus instead on 'the apprehension of the thing. ${ }^{75}$ The poetic circling around the thing itself, however, does not mean that the real disappears entirely: 'the real is only the base. But it is the base'. ${ }^{76}$ Though Stevens clearly introduces a far larger share of abstraction in his verse than O'Hara, his insistence on reality is nonetheless apparent in poems such as 'An Ordinary Evening in New Haven', where the haphazard aspect of the walk and its direct reference to a place firmly anchor its cantos in the occasion itself. ${ }^{77}$ While Stevens roots his poetry in the actual world, making it a part of the res itself', ${ }^{78}$ perhaps Ashbery goes one step further in his greater willingness to let go of a solid ground altogether. Ashbery's mental flow becomes a far more dominant mode in his later poetics, yet it is already present in his first volume. In 'Two Scenes', for example, the poet accepts that imitation and appearance-'we see us as we truly behave'-is sufficient: the poet can still claim that 'the train comes bearing joy', and that the 'day was warm and pleasant'. The dissolution of certainties is liberating and joyful: 'as laughing cadets say, "In the evening | Everything has a schedule, if you can find out what it is"' ${ }^{79}$ In Ashbery's poetic world, reality and the self recede with remarkable ease: one never arrives, one never is.

Ashbery's reliance on simile to describe a mode of behaving via the conjunction 'as' fits in well with Charles Altieri's recent theorizing of aspectual thinking. In my reading here, 'asness' complements celebratory pragmatism and quotidian poetics in its vindication of indeterminacy and its resistance to identity thinking. Altieri stresses that the aspectual mode is a dynamic, conditional 'way of envisioning poetry not as a sophisticated mode of naming but as a model for ways of thinking leery of the quest for this kind of authority'. ${ }^{80}$ While this mode is clearly a central tenet of the New York School poetic, it also demonstrates again the legacy of Filreis's languaged Stevens and Silverberg's queer modernism. Accordingly, one of the values of Ashbery's aspectual thinking - namely, his internalization of 'as' - is precisely that it has helped eventuate the post-war break with more conservative modes of modernist poetry as codified by the New Criticism. In addition, Altieri flags up that this mode should, at least in part, be attributed to Ashbery's reading of Stevens, which strengthens once more the case for reading the three poets together. ${ }^{81}$ The implications of Altieri reading Ashbery reading Stevens, however, lead us to question again O'Hara's dictum that poetry is experience. If

\footnotetext{
75 Stevens, 'An Ordinary Evening in New Haven', p. 404, and Davidson, p. 157.

76 Stevens, 'Materia Poetica', in Collected Poetry and Prose, pp. 916-20 (p. 917).

77 Gilbert, p. 98.

78 Stevens, 'An Ordinary Evening in New Haven', p. 404.

79 Ashbery, 'Two Scenes', in Collected Poems 1956-1987, p. 3.

${ }^{80}$ Charles Altieri, Wallace Stevens and the Demands of Modernity: Toward a Phenomenology of Value (Ithaca, NY: Cornell University Press, 2013), p. 135.

81 Ibid.
} 
that were truly the case, would his poetry not enact precisely the authority and stability that he wishes to unsettle? Though the undertone of anxiety in O'Hara's work shows an acute awareness of this epistemological bind, the poet's best work is successful in conveying the particulars and instantaneities of his lunchtime strolls, all the while creating a sense of intimacy without ever becoming too personal. 'Personism', as O'Hara defends puckishly, 'does not have to do with personality or intimacy': rather, it suggests 'overtones of love without destroying love's life'. ${ }^{82}$ It is the radical insistence on shifting presences, rather than a single monolithic presence, that prevents the poems from becoming static wholes.

Ashbery contributes to this understanding of the poem as an experience in itself by going beyond O'Hara's would-be tautological relation of text and occasion. The poet achieves this already in 'Some Trees', where a shifting, conditional, if not therefore undefined self is constituted even as it experiences the surrounding world:

you and I

Are suddenly what the trees try

To tell us we are.

Ashbery's poetic self is fluid in its radical dependency on occasion, and in its suggestion that we are

as far this morning

From the world as agreeing with it. ${ }^{83}$

In other words, the self-poetic or otherwise-is in perpetual motion: it is defined and constituted by its occasion, yet forever moving away from it. This dismisses neither the value nor the intersubjective drive of the self and the occasion: as at least one critic has recently argued, Ashbery's poetics suggest a reconciliation of 'pragmatist empiricism and romantic interiority' ${ }^{84} \mathrm{Or}$, as O'Hara aptly surmised in his review of Some Trees, the lyric figures in Ashbery's collection 'are all people who meet experience on the most articulate lyrical terms and this gives their meeting an absolute value beyond their meetings' ${ }^{85}$ In fact, the poem holds the Stevensian suggestion of 'the lonely lover joining the most intense rendezvous of paramours who are exactly as strange to themselves as to society. ${ }^{86}$ In Ashbery's terms, the poem offers

82 O'Hara, 'Personism', p. 499.

83 Ashbery, 'Some Trees', in Collected Poems 1956-1987, p. 26.

${ }^{84}$ Siobhan Phillips, The Poetics of the Everyday: Creative Repetition in Modern American Verse (New York: Columbia University Press, 2010), p. 203.

85 O'Hara, 'Rare Modern', p. 312.

${ }^{86}$ Alan Filreis, 'Descriptions without Places', in Visiting Wallace: Poems Inspired by the Life and 
the combination of a distanced, Romantic interiority with the simultaneous, pragmatist affirmation that ' $[\mathrm{w}] \mathrm{e}$ may touch, love, explain'. ${ }^{87}$

\section{Conclusion}

By reorganizing the clusters of poets to which we have become habituated, we may begin to notice how Ashbery shares both Stevens's modern Romanticism and O'Hara's primarily pragmatist conception of the fleeting, fluid self. As much as the self is defined and altered by its occasion, it can be argued that any complex writer's poetics is flexible, contingent, and resistant to all-tooneat, monolithic chronologies of influence: poets continuously move away from and revise their poetic predecessors just as poetics move away from stable definitions. My analysis of O'Hara's poetics, and its often ambiguous, tangential connections to Ashbery and Stevens, hopes to demonstrate the benefit of reading across boundaries and may help recast traditional models of literary influence. While a more conventional, linear reading of influence starting from the father figure of Stevens would altogether threaten to exclude O'Hara, whose rhetorical language is decidedly very different on the surface from the older poet's, a triangulation of both these writers' poetics via Ashbery helps define their shared affinities with occasional poetry and celebratory pragmatism circa 1950. In addition, the question of poetry's attempt to coincide with its occasion reveals poetic connections and tropes that would otherwise be less apparent. It makes clear, among other things, how there is an inherently social nature to the poetics of three writers that have been dubbed, to varying degrees, elitist or private: with these three poets, the social aspects of the occasion and the ecstasies of the everyday serve to counter the temptations of a removed and purely aestheticized poetics.

In such a triangulated, less chronologically organized reading practice it becomes feasible and rewarding to reverse the conventional reading and see Stevens in the light of the New York School. After all, as Phillips reminds us, poetic kinships 'emphasize aspects of the influencer as well as those influenced'. ${ }^{88}$ A reverse reading undermines the critical insistence on belatedness and demands that influence be regarded as extending both ways. It helps us avoid what Rachel Galvin describes as 'presentism': the teleological view that envisions 'a poetic development inexorable as the flow of the Mississippi River toward its delta, depositing the alluvium of poetry in the contemporary moment'. ${ }^{89}$ If authors are read only in the light of the Great Author

Work of Wallace Stevens, ed. by Dennis Barone and James Finnegan (Iowa City: University of Iowa Press, 2009), pp. xi-xii (p. xi).

87 Ashbery, 'Some Trees', p. 26.

88 Phillips, 'Stevens and an Everyday New York School', p. 95.

89 Rachel Galvin, 'Stevens, Auden: Whose Age Was It Anyway-and Why Do We Care?', Wallace Stevens Journal, 37 (2013), 155-66 (p. 156). 
coming before them, comparative studies become a lot more strained, and a whole lot less revealing. In this sense, a welcome and unexpected result of my reconfiguration is that it reconsiders Stevens's position within American twentieth-century poetry, now that he is quickly becoming a more marginal figure within the New Modernist studies. As Gilbert observed recently, 'Stevens doesn't command a central place in the large perspectives on modernism most in vogue at present, which tend to emphasize cultural, social, and institutional contexts rather than philosophical, aesthetic, and formal concerns. ${ }^{90}$ Perhaps my attempts here to read Stevens as an unexpected member of O'Hara's and Ashbery's crowd-following Epstein's insistence on 'the social, material constitution of poetry and its institutions' ${ }^{91}$ - could be a first step towards reclaiming the poet's importance for the history of American poetry rather than for modernist studies.

\section{University of ANTwERP, FWO VlaANDEREN}

LESLEY JANSSEN

90 Roger Gilbert, review of Modernism and Literature: An Introduction and Reader, ed. by Mia Carter and Alan Warren Friedman, and A Handbook of Modernism Studies, ed. by Jean-Michel Rabaté, in Wallace Stevens Journal, 38 (2014), 105-07 (p. 105).

${ }^{91}$ Epstein, p. 8. 